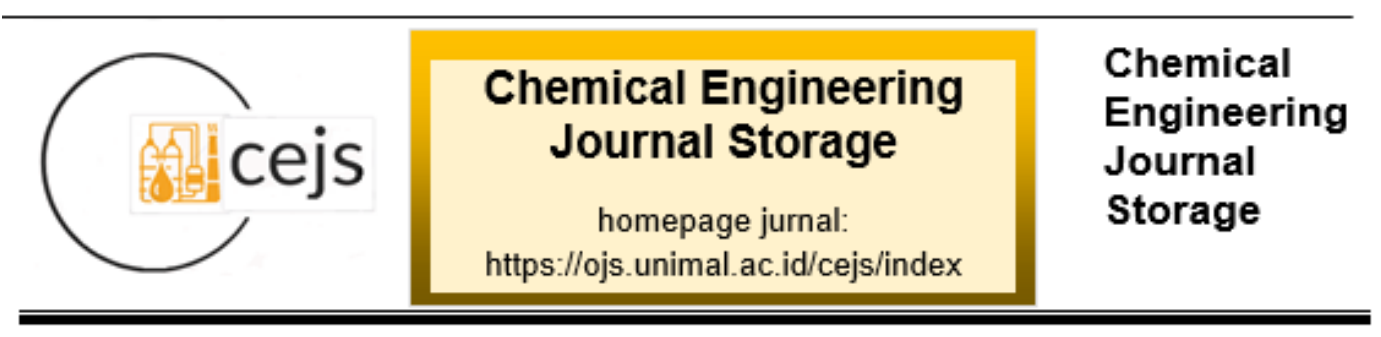

\title{
PENGAMBILAN ZAT BETASIANIN DARI KULIT BUAH NAGA MERAH (HYLOCEREUS POL YRHIZUS) SEBAGAI PEWARNA MAKANAN ALAMI DENGAN METODE EKSTRAKSI
}

\section{Cut Sisin Mehita Sandy ${ }^{1}$, Ishak ${ }^{1}$, Syamsul Bahri ${ }^{1}$, Masrulita $^{1}$, Rizka Nurlaila ${ }^{1}$ \\ ${ }^{1}$ Jurusan Teknik Kimia, Fakultas Teknik, Universitas Malikussaleh Korespondensi: HP: 0813-6290-8162,E-mail: ishak@unimal.ac.id}

\begin{abstract}
Abstrak
Betasianin adalah pigmen berwarna merah-violet dan kuning-orange yang banyak terkandung pada buah, bunga, dan jaringan vegetatif. Betalain adalah pigmen kelompok alkaloid yang larut air, pigmen bernitrogen, dan merupakan pengganti anthocyanin pada setiap bagian besar family tanaman ordo Caryophyllales, termasuk Amaranthaceae, dan bersifat mutual eksklusif dengan pigmen antosianin. Waktu ekstraksi dan suhu ekstraksi sangat mempengaruhi pH, kadar air, intensitas warna dan masa penyimpanan zat warna. Semakin tinggi waktu ekstrak dan semakin rendah suhu nya maka semakin tinggi intensitas warna yang dihasilkan. Suhu ekstraksi lebih dari $50^{\circ} \mathrm{C}$ menyebabkan penurunan intensitas warna, hal ini disebabkan karena zat betasianin tidak mampu bertahan atau rusak pada suhu tinggi. Kualitas zat warna betasianinnya tidak pengaruh dengan meningkatnya kadar air yang dihasilkan oleh suhu yang rendah. Akan tetapi masa ketahanan zat pewarnanya saja yang tidak bisa bertahan dalam jangka yang panjang. Didapatkan intensitas warna terbaik pada suhu $40^{\circ} \mathrm{C}$ dalam waktu perebusan selama 3 jam. Dengan $p H$ 5,1, nilai absorbansi 1,725, kadar air 30,9, dan masa penyimpanan sampai 5 hari.
\end{abstract}

Kata kunci: Betasianin, Kulit Buah Naga, Ekstraksi, Suhu, Waktu

\section{Pendahuluan}

Buah naga merah (Hylocereus polyrhizus) atau yang dikenal sebagai Pitaya (dalam bahasa Latin Amerika) kaya akan betalain. Kelebihan kulit buah naga merah (Hylocereus polyrhizus) sangat memiliki banyak manfaat diantaranya bagi kesehatan, pewarna alami makanan dan minuman. Kulit buah naga mengandung zat warna alami antosianin cukup tinggi. Antosianin merupakan zat warna yang berperan memberikan warna merah berpotensi menjadi pewarna alami untuk 
pangan dan dapat dijadikan alternatif pengganti pewarna sintetis yang lebih aman bagi kesehatan (Citramuk, 2008)

Hal menarik dari buah naga adalah manfaat dari kulit buahnya sebagai pewarna alami untuk makanan dan minuman. Pada dunia kesehatan kulit buah naga dapat dijadikan obat herbal yang berkhasiat sebagai antioksidan alami (Cahyono, 2009)

\section{Tinjauan Pustaka}

\section{Pengertian Zat Betasianin}

Betasianin merupakan pigmen berwarna merah-violet dan kuning-orange yang banyak terdapat pada buah, bunga, dan jaringan vegetatif. Betalain adalah pigmen kelompok alkaloid yang larut air, pigmen bernitrogen, dan merupakan pengganti anthocyanin pada sebagian besar family tanaman ordo Caryophyllales, termasuk Amaranthaceae, dan bersifat mutual eksklusif dengan pigmen antosianin. Sifat ini berarti bahwa pigmen betalain dan antosianin tidak pernah dijumpai bersama-sama pada satu tanaman. Oleh karena itu pigmen betalain sangat signifikan dalam penentuan taksonomi tanaman tingkat tinggi. (Faridah et al., 2015)

\section{Zat pewarna alami}

Pewarna makanan alami sudah dikenal oleh masyarakat Indonesia sejak zaman dahulu, seperti daun suji, kunyit, kesumba dan sebagainya. Bahan alami tersedia dalam jumlah yang berlimpah. Namun penggunaan pewarna makanan alami semakin lama semakin ditinggalkan produsen makanan. Hal ini disebabkan oleh karena kurang praktis dalam pemakaiannya terkait dengan belum adanya pewarna alami yang dijual di pasaran sehingga produsen makanan harus membuat sendiri pewarna makanan yang dibutuhkan tersebut. Di samping itu kelemahan dari penggunaan pewarna alami adalah warna yang kurang stabil yang bisa disebabkan oleh perobahan $\mathrm{pH}$, proses oksidasi, pengaruh cahaya dan pemanasan, sehingga intensitas warnanya sering berkurang selama proses pembuatan 
makanan. Akibatnya produsen makanan banyak yang beralih ke pewarna makanan sintetis. (Nugraheni, 2014)

\section{Klasifikasi Buah Naga ( Hylocereus polyrhizus )}

Kingdom Plantae

Sub kingdom Plantea

Super divisi Tracheobionta (tanaman vascular)

Divisi Spermathophyta (tumbuhan berbiji)

Kelas Magnoliophyte (tanaman dikotil atau berkeping dua

Ordo Caryophyllases

Famili Cactaceae (kaktus)

Subfamili Cactoideae

Suku (tribe) Hylocereae

Genus $\quad$ Hylocereus (Berger) Britt dan Rose

Spesies Hylocereus undatus (Haw.) Britt dan rose,selenecereus

sp.

(Sumber: Heckman, Pinto, \& Savelyev, 1967)

\section{Pengaruh Pemanasan terhadap Serapan Pigmen Betalain}

Panas merupakan faktor yang sangat penting terhadap kestabilan pigmen betalain. Selama proses pemanasan, kemungkinan terjadi pemutusan ikatan yang menyebabkan terjadi pengurangan warna merah menjadi merah pucat ataupun berubah menjadi kuning terang. Selain oleh panas, perubahan warna ini juga dapat disebabkan oleh basa. Pemutusan ikatan ini akan menghasilkan dua senyawa yaitu 
asam betalamat (kuning terang) dan siklo-DOPA (tidak berwarna). (Yelfira sari 2018)

\section{Ekstraksi}

Ekstraksi merupakan proses pemisahan bahan dari campurannya dengan menggunakan pelarut yang sesuai. Proses ekstraksi dihentikan ketika tercapai kesetimbangan antara konsentrasi senyawa dalam pelarut dengan konsentrasi dalam sel tanaman. Setelah proses ekstraksi, pelarut dipisahkan dari sampel dengan penyaringan. Ekstrak awal sulit dipisahkan melalui teknik pemisahan tunggal untuk mengisolasi senyawa tunggal. Oleh karena itu, ekstrak awal perlu dipisahkan ke dalam fraksi yang memiliki polaritas dan ukuran molekul yang sama. (Mukhtarini, 2011)

\section{Metode dan bahan}

Bahan baku pada penelitian ini adalah kulit buah naga merah yang di peroleh di daerah lhokseumawe, bahan pendukung pada penelitian ini yaitu aquades. Peralatan yang digunakan pada penelitian ini adalah beaker gelas, Erlenmeyer, hot plate, pisau, Aluminium foil, thermometer, neraca analitik, pipet tetes, spektrofotometer Uv-Vis, $\mathrm{pH}$ meter, wadah, stopwatch. Pelaksanaan pembuatan pewarna makanan alami dilaksanakan dengan tiga variabel yaitu variabel tetap, variabel bebas, dan variabel terikat, Variabel tetap pada penelitian ini adalah berat sampel kulit buah naga merah sebanyak 50 gr dan volume aquades sebanyak 100 $\mathrm{ml}$, variabel bebas nya yaitu waktu dan suhu. suhu ekstraksi $\left(40^{\circ} \mathrm{C}, 50^{\circ} \mathrm{C}, 60^{\circ} \mathrm{C}\right.$, dan $70^{\circ} \mathrm{C}$ ) dan lama waktu ekstraksi (1 jam, 1,5 jam, 2 jam, 2,5 jam, dan 3 jam). Dan variabel terikat nya yaitu uji $\mathrm{pH}$, uji kadar air, uji intensitas warna, uji organoleptik.

Pertama, kulit buah naga merah di cuci bersih lalu dipotong berukuran sedang kemudian ditimbang sebanyak 50 gram dan dimasukkan kedalam wadah, kemudian aquades dimasukkan kedalam Erlenmeyer sebanyak $100 \mathrm{ml}$ lalu dipanaskan menggunakan hot plate dengan suhu $40^{\circ} \mathrm{C}$, setelah aquades 
dipanaskan sampai suhu $40^{\circ} \mathrm{C}$ lalu dimasukkan kulit buah naga merah kedalam Erlenmeyer jaga suhu agar tetap berada pada suhu $40^{\circ} \mathrm{C}$ selama 1 jam. Setelah itu ekstrak kulit buah naga merah di saring dan diambil filtratnya, kemudian simoan ekstrak kulit buah naga merah ini kedalam botol. Ulangi prosedur kerja diatas dengan waktu dan suhu pemanasan yang berbeda untuk waktu pemanasan diganti dengan 1,5 jam, 2 jam, 2,5 jam dan 3 jam dan suhu $50^{\circ} \mathrm{C}, 60^{\circ} \mathrm{C}$, dan $70^{\circ} \mathrm{C}$. Setelah diperoleh ekstrak kulit buah naga merah, kemudian akan di uji dengan beberapa variabel terikat yaitu : (1) Uji $\mathrm{pH}$ dilakukan dengan cara siapkan peralatan $\mathrm{pH}$, kemudian kalibrasi alat $\mathrm{pH}$ meter dengan larutan buffer (aquades), kemudian celupkan elektroda ke dalam beaker gelas yang telah berisi ekstrak kulit buah naga merah, lalu catat $\mathrm{pH}$ yang ditampilkan pada layer $\mathrm{pH}$. (2) Uji kadar air ilakukan dengan cara Sampel setelah di ekstrak ditimbang dan diletakkan di alumunium foil. Setelah itu sampel yang sudah ditimbang di masukkan kedalam oven. Setelah 2 jam sampel di keluarkan dari dalam oven untuk ditimbang lagi. Kadar air sampel ditentukan langsung dari proses pengeringan dengan cara pengering oven selama 2 jam dengan suhu $105^{\circ} \mathrm{C}$. Kadar air dihitung dengan menggunakan rumus: Kadar air $=\frac{a-b}{a} x 100 \%$. (3) Uji intensitas warna dilakukan dengan cara nyalakan spektofotometer kemudian bersihkan kuvet atau tabung reaksi kemudian tuangkan aquades di kedua kuvet, Setelah itu masukkan dalam alat spektofometer untuk di kalibrasi, Setelah beberapa menit keluarkan 1 kuvet yang berisi aquades tadi untuk diganti dengan larutan sampel, Lalu masukkan kuvet yang sudah berisi air sampel itu kedalam spektrofotometer, Ukur absorbansi sampel, Setelah beberapa menit air yang berisi sampel tadi diambil kembali untuk di uji dengan larutan lain yang berbeda suhu dan waktu, Ulangi eksperimen diatas dengan waktu dan suhu yang berbeda. (4) Uji umur simpan ketahanan pewarna makanan ini bisa secara Organoleptik dimana uji umur simpan pewarna makanan ini dengan cara di amati dan dicatat hasil setiap hari sekali, ditandai dengan ciri ciri pewarna makanan yang sudah habis masa bisa dilihat dengan pewarna yang awalnya warna nya pekat menjadi pudar,yang awalnya tidak berbau akhirnya mengeluarkan bau, dan juga $\mathrm{pH}$ nya bertambah dari $\mathrm{pH}$ sebelumnya. 


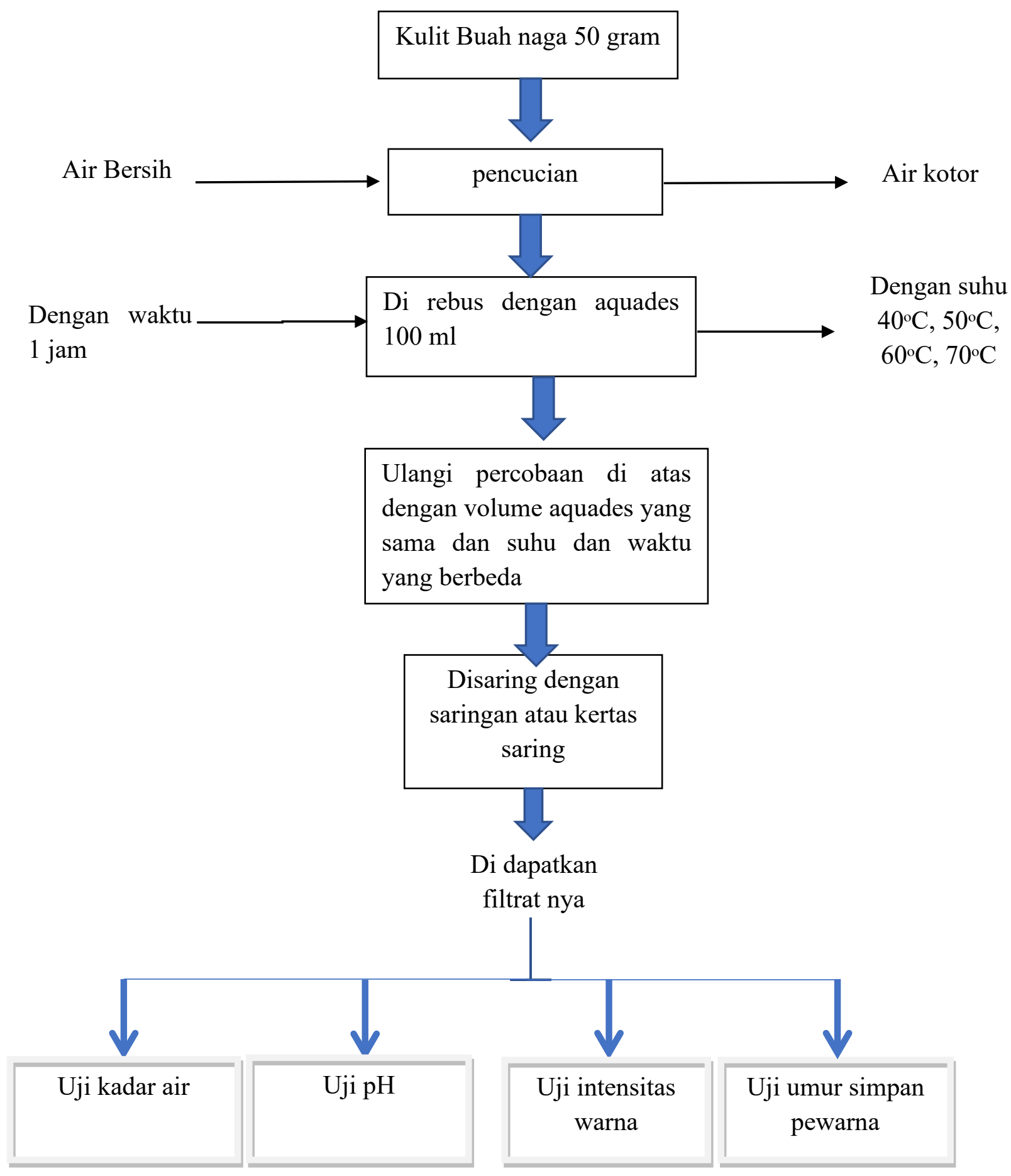

\section{Hasil dan pembahasan}


Kulit buah naga diketahui mengandung zat betasianin melalui alat HPLC yang telah diteliti sebelumnya oleh Anni Faridah dimana alat ini mendeteksi adanya senyawa betasianin dikarenakan pengukuran rentang panjang gelombang nya itu sekitar 500-550 nm, pengukuran ini dilakukan karena panjang gelombang tersebut merupakan panjang gelombang dari kelompok senyawa betasianin yang ada. Dengan sifat kimia betasianin didapatkan senyawa alkaloid yang bersifat larut dalam air atau dalam pelarut - pelarut organik lainnya, dan pigmen bernitrogen. (Faridah et al., 2015). Selain itu zat betasianin ini mengandung senyawa flavonoid yang dimana sifat kimianya itu agak asam karena mengandung vitamin $\mathrm{C}$ dan sifat fisiknya itu dapat larut dalam larutan polar seperti air, etanol dan methanol.

\subsection{Pengaruh Waktu Ekstraksi dan Suhu Ekstraksi Terhadap pH pada volume aquades $100 \mathrm{ml}$ dan berat sampel 50 gram}

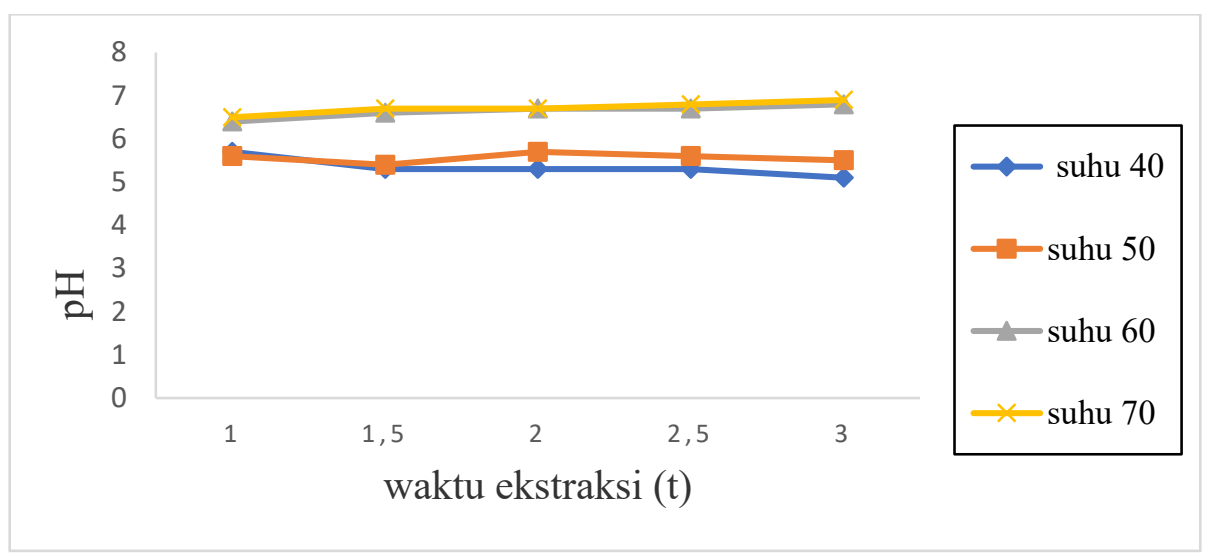

Berdasarkan grafik diatas, $\mathrm{pH}$ tertinggi adalah 6,9 yang berada pada suhu ekstraksi $70^{\circ} \mathrm{C}$ dengan waktu 3 jam. Sedangkan $\mathrm{pH}$ terendah adalah 5,1 yang berada pada suhu ekstraksi $40^{\circ} \mathrm{C}$ dengan waktu 3 jam. Adapun grafik hubungan antara suhu ekstraksi terhadap $\mathrm{pH}$ pada volume $100 \mathrm{ml}$ aquades dapat diliat pada Gambar 1. Berdasarkan gambar 1 derajat keasaman $(\mathrm{pH})$ yang tertinggi adalah 6,9 pada suhu $70^{\circ} \mathrm{C}$ dan waktu 3 jam dan sedangkan $\mathrm{pH}$ terendah adalah 5,1 pada suhu $40^{\circ} \mathrm{C}$ waktu 3 jam. Hal ini disebabkan karena semakin tinggi suhu perebusan maka zat betasianin yang dihasilkan pada kulit buah naga semakin berkurang. 
karena kulit buah naga ini stabil pada pH 5-6 dan tidak mendekati angka $\mathrm{pH}$ netral.

\subsection{Pengaruh Waktu Ekstraksi dan Suhu Ekstraksi Terhadap Kadar Air.}

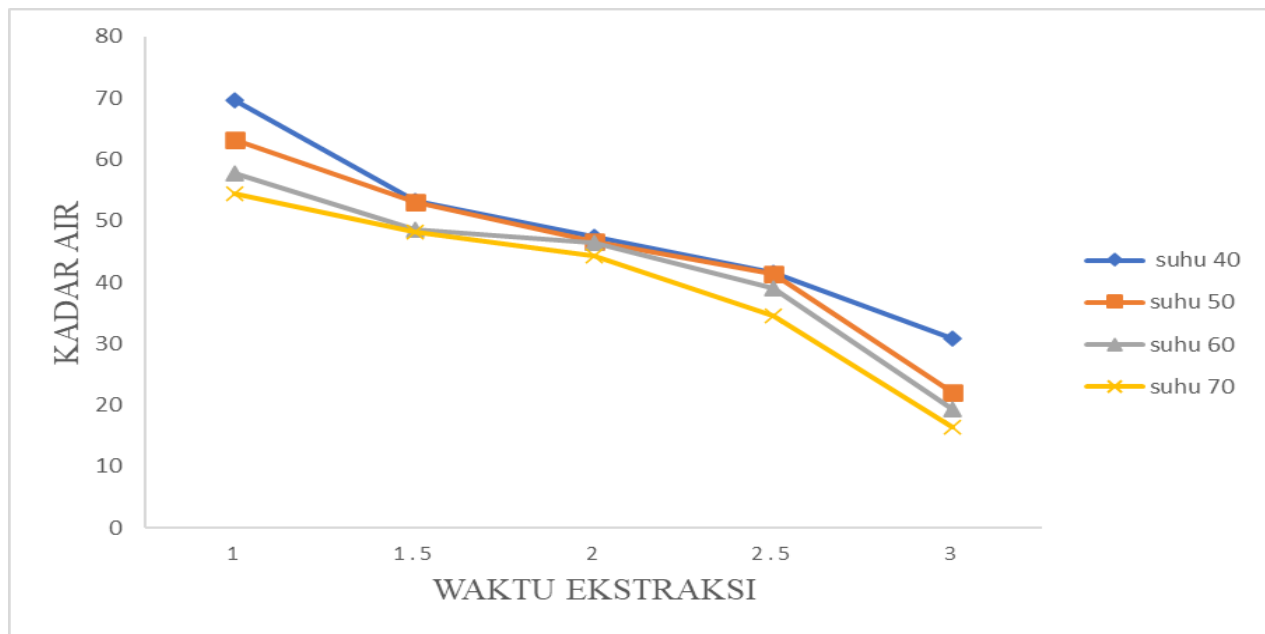

Grafik 2 menunjukkan kadar air tertinggi adalah 69,6\% pada suhu 40 waktu 1 jam. Sedangkan kadar air terendah adalah 16,38\% pada suhu 70 waktu 3 jam. Kadar air yang terkandung dalam zat warna tersebut merupakan salah satu parameter dari ketahanan produk atau daya simpan produk bergantung pada kadar air yang diperoleh, semakin sedikit kadar airnya, maka semakin lama ketahanan atau daya simpan produk tersebut. Maka ini berbanding terbalik dengan nilai intensitas warna yang dihasilkan oleh zat betasianin, karena zat betasianin ini stabil pada suhu $40-50^{\circ} \mathrm{C}$, diatas waktu itu zat betasianin itu sudah rusak dan tidak dapat menghasilkan zat betasianin yang baik. Akan tetapi kualitas warna tidak terpengaruh pada kadar air yang tinggi dikarenakan kadar air ini hanya sebagai parameter daya simpan saja. Maka dari itu pewarna alami ini tidak dapat disimpan dalam jangka lama. Dan hanya bisa di pakai dalam jangka waktu yang singkat saja. 


\subsection{Pengaruh Waktu Ekstraksi Dan Suhu Ekstraksi Terhadap Intensitas} Warna Pada Volume 100 ml Aquades Dan Berat Sampel 50 gram

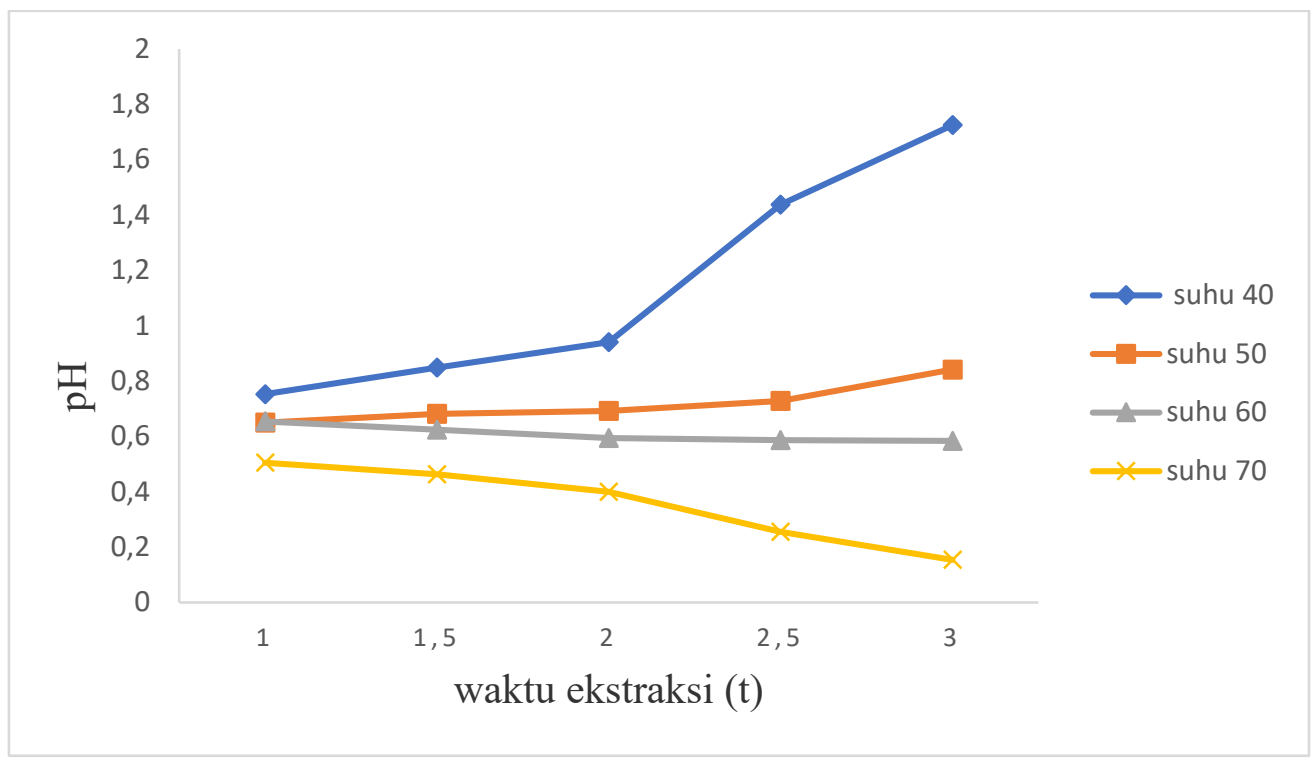

Grafik 3 diatas mendapatkan nilai 1,725 sebagai warna tertinggi, nilai ini diperoleh pada suhu ekstraksi $40^{\circ} \mathrm{C}$ dan waktu 3 jam. Hal ini dikarenakan semakin rendah suhu dan semakin tinggi waktu ekstraknya maka zat betasianin yang dihasilkan akan semakin banyak. Suhu yang terlalu tinggi akan menyebabkan kerusakan zat betasianin sehingga warna yang dihasilkan pun menurun. Hal ini dapat dilihat pada suhu $70^{\circ} \mathrm{C}$.

\subsection{Tabel Hasil Uji Organoleptik (Uji Umur Simpan) Pada Ekstrak Kulit Buah Naga Merah}

Untuk menguji umur simpan ini yang pertama kali kita bisa lihat dari hasil nilai absorbansi yang dihasilkan, 5 nilai absorbansi tertinggi inilah yang diambil untuk menguji ketahanan umur simpan zat betasianin agar diketahui perbandingan antara suhu dan waktu serta nilai absorbansinya. Selanjutnya di uji ketahanan nya dengan mengecek $\mathrm{pH}$, warna dan bau setiap harinya. Apabila $\mathrm{pH}$ nya sudah bertambah dari $\mathrm{pH}$ sebelumnya dan sudah berubah warna serta sudah mengeluarkan bau maka umur simpan nya sudah habis masa. Tabel-tabel dibawah ini akan menunjukkan bagaimana perbandingan setiap harinya antara $\mathrm{pH}$, warna, dan bau yang dihasilkan setiap hari. 
Tabel 1 Dengan waktu 1 jam suhu $40^{\circ} \mathrm{C}$

\begin{tabular}{|c|c|c|c|c|}
\hline No & Hari & pH & Warna & Aroma \\
\hline 1. & Hari ke-1 & 5,3 & Merah & Tidak berbau \\
2. & Hari ke-2 & 5.3 & Merah & Tidak berbau \\
3. & Hari ke-3 & 6.6 & Merah pudar & Berbau \\
\hline
\end{tabular}

Tabel 2 Dengan waktu 1,5 jam suhu $40^{\circ} \mathrm{C}$

\begin{tabular}{|c|c|c|c|c|}
\hline No & Hari & pH & Warna & Aroma \\
\hline 1. & Hari ke-1 & 5,3 & Merah & Tidak berbau \\
2. & Hari ke-2 & 5,3 & Merah & Tidak berbau \\
3. & Hari ke-3 & 6,6 & Merah pudar & Berbau \\
\hline
\end{tabular}

Tabel 3 dengan waktu 2 jam suhu $50^{\circ} \mathrm{C}$

\begin{tabular}{|c|c|c|c|c|}
\hline No & Hari & pH & Warna & Aroma \\
\hline 1. & Hari ke-1 & 5,4 & Merah & Tidak berbau \\
2. & Hari ke-2 & 5,4 & Merah & Tidak berbau \\
3. & Hari ke-3 & 6,7 & Merah pudar & Berbau \\
\hline
\end{tabular}


Tabel 4 dengan waktu 2,5 jam suhu $40^{\circ} \mathrm{C}$

\begin{tabular}{|c|c|c|c|c|}
\hline No & Hari & pH & Warna & Aroma \\
\hline 1. & Hari ke-1 & 5,3 & Merah & Tidak berbau \\
2. & Hari ke-2 & 5,3 & Merah & Tidak berbau \\
4. & Hari ke-3 & 5,3 & Merah & Tidak Berbau \\
& Hari ke-4 & 6,7 & Merah pudar & Berbau \\
\hline
\end{tabular}

Tabel 5 dengan waktu 3 jam suhu $40^{\circ} \mathrm{C}$

\begin{tabular}{|c|c|c|c|c|}
\hline No & Hari & pH & Warna & Aroma \\
\hline 1. & Hari ke-1 & 5,1 & Merah & Tidak berbau \\
3. & Hari ke-2 & 5,1 & Merah & Tidak berbau \\
4. & Hari ke-3 & 5,1 & Merah & Tidak Berbau \\
5. & Hari ke-4 & 5,1 & Merah & Tidak berbau \\
& & 6,7 & Merah Pudar & Berbau \\
\hline
\end{tabular}

Berdasarkan tabel diatas bisa dilihat bahwa semakin lama waktu ekstraksi maka waktu penyimpanan zat pewarnanya pun bisa bertahan lama hingga 5 hari, zat pewarna ini tidak dapat bertahan lebih dari 5 hari, dikarenakan suhu terbaiknya itu di suhu $40^{\circ} \mathrm{C}$ dan kadar air yang baik itu di suhu $70^{\circ} \mathrm{C}$, dengan hal ini berbanding terbalik dengan kualitas zat pewarna yang baik, karena di suhu $60^{\circ} \mathrm{C}$ keatas kualitas zat betasianin ini malah semakin hilang zat betasianinnya, tetapi sebaliknya kadar air yang dihasilkan semakin sedikit, maka dari itu zat pewarna betasianain ini tidak dapat digunakan dalam jangka panjang, karena 
mengandung kadar air yang lumayan banyak hal ini dapat mengakibatkan keawetan zat pewarna tersebut.

\section{Kesimpulan dan saran}

Waktu ekstraksi dan suhu ekstraksi sangat mempengaruhi $\mathrm{pH}$, kadar air, intensitas warna dan masa penyimpanan zat warna. Semakin tinggi waktu ekstrak dan semakin rendah suhu nya maka semakin tinggi intensitas warna yang dihasilkan. Suhu ekstraksi lebih dari $50^{\circ} \mathrm{C}$ menyebabkan penurunan intensitas warna, hal ini disebabkan karena zat betasianin tidak mampu bertahan atau rusak pada suhu tinggi. Kualitas zat warna betasianinnya tidak pengaruh dengan meningkatnya kadar air yang dihasilkan oleh suhu yang rendah. Akan tetapi masa ketahanan zat pewarnanya saja yang tidak bisa bertahan dalam jangka yang panjang. Didapatkan intensitas warna terbaik pada suhu $40^{\circ} \mathrm{C}$ dalam waktu perebusan selama 3 jam. Dengan pH 5,1, nilai absorbansi 1,725, kadar air 30,9, dan masa penyimpanan sampai 5 hari.

Zat pewarna ini sebaiknya dilanjutkan dengan menggunakan metode freezy drying untuk menghasilkan pewarna makanan dalam bentuk serbuk agar masa ketahananya itu lebih tahan lama.

\section{Daftar Pustaka}

1. Cahyono. (2009). Uji Aktivitas Antioksidan Ekstrak Etanol Kulit Buah Naga Merah Super ( Hyclocereus costaricencis ). 05(01), 14-21.

2. Citramuk. (2008). BAB I PENDAHULUAN 1.1 Latar Belakang. 1-7.

3. Faridah, A., Holinesti, R., Syukri, D., Teknik, F., Negeri, U., Teknik, F., \& Universitas, P. (2015). Identifikasi Pigmen Betasianin Dari Kulit Buah Naga Merah (Hylocereus Polyrhizus). Jurnal Pendidikan Dan Keluarga, 7(18), 147-154.

4. Heckman, J. J., Pinto, R., \& Savelyev, P. A. (1967). Klasifikasi Buah Naga Buah. Angewandte Chemie International Edition, 6(11), 951-952., 9-27.

5. Mukhtarini. (2011). "Ekstraksi, pemisahan senyawa, dan identifikasi senyawa aktif." Jurnal of Pharmacy, $V, 361$.

6. Nugraheni, M. (2014). Pewarna Alami Sumber Aplikasinya Pada Makanan dan Kesehatan. 
Cut Sisin Mehita / Chemical Engineering Journal Storage $1: 2$ (Oktober 2021) 107-119

7. Yelfira sari. (2018). Pengaruh Pemanasan Terhadap Kestabilan Pigmen Betalain Dari Buah Naga Merah (Hylocereus Polyrhizus) Yelfira. 37-42. 